(ППетрова А.С., Кондратюк В.Є., Карпенко О.В., 2021

doi: 10.37321/nefrology.2021.29-06

Удк: 616.61-036.12-036.17-07-085-78 : 616.155.194

\title{
ВПЛИВ МЕЛАТОНІНУ У СКЛАДІ КОМПЛЕКСНОГО ЛІКУВАННЯ НА КЛІНІКО-ЛАБОРАТОРНІ ПОКАЗНИКИ АНЕМІЇ ТА АКТИВНІСТЬ СИСТЕМНОГО ЗАПАЛЕННЯ У ХВОРИХ НА ХРОНІЧНУ ХВОРОБУ НИРОК V Д СТАДІЇ, ЩО ЗНАХОДЯТЬСЯ НА ЛІКУВАННІ ГЕМОДІАЛІЗОМ
}

\author{
ПЕТРОВА А.С., КОНДРАТЮК В.Є., КАРПЕНКО О.В.
}

\author{
Національний медичний університет імені О.О. Богомольця \\ Київ, Україна
}

Резюме

\begin{abstract}
Актуальність. Розвиток та прогресування хронічної хвороби нирок (XXH) асоціюється з несприятливими змінами у всіх сферах життя пацієнтів на гемодіалізі (ГД). Не дивлячись на значний прогрес в сучасній медицині, пошук підвищення ефективності лікування анемії та системного хронічного запалення у хворих на ГД $є$ актуальним завданням сьогодення.

Мета дослідження. Проаналізувати ефективність препарату мелатоніну у хворих на XXH V стадії, що лікуються гемодіалізом для корекції анемії та зменшення проявів запалення, шляхом додавання його до стандартного лікування.

Матеріали та методи. Обстежено 130 пацієнтів (50 \% жінки) на XXH 5 стадії, що знаходяться на лікуванні методом гемодіалізу. Згідно дизайну дослідження в залежності функціонування епіфізу та схеми лікування сформовано три групи хворих. В основну (I) групу увійшло 70 хворих на XXH V стадії, що лікуються ГД з порушеною МФЕ, котрі до стандартної терапії отримували препарат МТ. Групу порівняння Ila $(\mathrm{n}=40)$ склали хворі на XXH V стадії з порушеною МФЕ, котрі отримували стандартну терапію. В групу порівняння IIб $(n=20)$ увійшли хворі на XXH V стадії зі збереженою МФЕ на стандартній терапії. Усім хворим на старті лікування та після 8-тижневого лікування проведено клініко-лабораторні дослідження, які включали в себе загальноклінічний та біохімічний аналіз крові, та обов'язкове визначення концентрації мелатоніну в слині.
\end{abstract}

Результати. Додавання мелатоніну до комплексної терапії у хворих на ГД демонструє зменшення проявів анемії (підвищення рівня Нb на 14,3 \%, p < 0,001), покращення показників обміну заліза (підвищення рівня трансферину на $12 \%, p<0,001$ ), білкового обміну (підвищення рівня альбуміну на 11,8 \%, p < 0,001) та системного запалення (зниження рівня СРБ у 3 рази, p < 0,001), що свідчить про протизапальні властивості МТ і його здатність покращувати метаболізм заліза та білку, усуваючи їх дефіцит.

Висновки. Результати проведеного дослідження демонструють зменшення проявів анемії та системного запалення у хворих на XXH V стадії, що лікуються ГД, шляхом нормалізації рівнів Нb, показників обміну заліза, СРБ, феритину та альбуміну на тлі додаткового призначення препарату МТ до стандартного лікування хворих на ГД. Отримані результати підтверджують дані інших експериментальних досліджень, в яких продемонстровано антиоксидантні, протизапальні та імунологічні властивості МТ. Широкий спектр функцій МТ дозволяє рекомендувати його додаткове призначення до комплексного лікування хворим на XXH V стадії, що лікуються методом гемодіалізу.

Ключові слова: Хронічна хвороба нирок, гемодіаліз, епіфіз, мелатонін, мелатонінутворювальна функція епіфізу, анемія, гемоглобін, запалення, феритин, С-реактивний білок, альбумін.

Вступ. Прогресування хронічної хвороби нирок (XXH) досить часто супроводжується розвитком анемії та синдрому хронічного запалення, особливо у хворих, що протягом тривалого часу знаходяться на лікування методом гемодіалізу (ГД). Анемія, як відомо $є$ найбільш раннім та розповсюдженим ускладненням XXH, найпоширенішими причинами якого $€$ зменшений синтез 
ендогенного еритропоетину, абсолютний або функціональний дефіцит заліза, неадекватна доза діалізу, вторинний гіперпаратиреоз, дефіцит карнітину та вітамінів [1]. Не варто також забувати про періодичні крововтрати, обумовлені втратою крові в діалізному контурі та частими лабораторними дообстеженнями хворих [2, 3].

За даними українського Національного реєстру хворих на XXН, станом за 2017 рік у пацієнтів на нирково-замісній терапії (НЗТ) рівень гемоглобіну (Нб) нижче цільового значення фіксувався у 51,7\% хворих на ГД та у 40,5 \% хворих, що отримували лікування методом гемодіафільтрації (ГДФ) [4].

Проведені міжнародні дослідження на підставі даних результатів Dialysis Outcomes and Practice Patterns Study демонструють наявність анемії від 23\% до $77 \%$ хворих на XXH 5 стадії, що лікуються ГД. За даними результатів United States Renal Data System, частота анемії серед пацієнтів, що лікуються діалізними методами у Сполучених Штатах Америки становить близько $58 \%[5,6]$.

Нажаль, серед хворих української діалізної популяції цільовий рівень Нб досягається лише у 20 \%, що значно нижче за показники інших країн. Так, в країнах Західної Європи цільове значення Нб на тлі лікування досягають біля 53 \% хворих (Милованова Л.Ю. та співавтор., 2009).

Не менш поширеним явищем, яке тягне за собою ряд ускладнень у хворих на ГД є синдром хронічного запалення. Розвиток хронічного запалення пов'язаний з багатофакторними чинниками, серед яких може бути падіння кліренсу прозапальних цитокінів, розвиток ендотоксемії $[7,8,9,10,11,12]$ та зменшення рівню антиоксидантів, що збільшують ризик кардіоваскулярних ускладнень та смертності хворих на ГД [13].

Важкість корекції анемії та синдрому хронічного запалення наштовхують на пошук нових методів їх лікування у хворих на НЗТ.

Останніми роками все більшу увагу наукового світу привертає гормон епіфізу - мелатонін (МТ), ритмам продукції якого підпорядковані всі ендогенні біоритми організму людини. МТ знижує утворення прозапальних цитокінів та попереджає процеси оксидативного стресу, який розвивається не тільки на тлі хронічної інтоксикації та запалення при XXH, а й при корекції анемії препаратами заліза чи еритропоетинів [14, 15]. Проте порушення мелатонінутворювальної функції епіфізу (МФЕ) у хворих на ГД та її зв>язок з розвитком анемії та хронічного системного запалення $€$ маловивченим питанням, що потребує подальших досліджень.

Матеріали та методи. Дизайн дослідження включав у себе проспективне дослідження із залученням 130 хворих (чоловіків - 65, жінок 65) з діагнозом XXН 5 Д стадії, які знаходилися на лікуванні ГД. Середній вік обстежених хворих склав 58,5 [43; 66] років.

Всі хворі отримували лікування методом ГД в умовах комунального некомерційного підприємства «Київський міський центр нефрології та діалізу».

Критеріями включення слугували: вік старше 18 років, лікування методом ГД тривалістю $\geq 3$ місяців, тижневий діалізний час не менше 12 годин, показник ефективності адекватності ГД за eKt $/ v \geq 1,4$, потік крові на рівні 250-300 мл/хв, наявність добровільної інформованої письмової згоди на участь в дослідженні, відсутність ендокринологічних, онкологічних, ревматологічних захворювань та гострих інфекційних процесів будь-якої етіології [3].

Під час дослідження всім хворим проведене стандартне обстеження, яке включало загальноклінічні, біохімічні та інструментальні методи дослідження.

Всім обстежуваним проведено визначення концентрації МТ в слині імуноферментним методом 3 використанням набоpy Human MS (Melatonin Sulfate) ELISA Kit, Elabscience. Забір матеріалу проводили в денний та нічний час, переважно в весняно-літній період, при мінімальному освітленні 30 Ix. Використовувалась нестимульована слина в об'ємі 1 мл, забір якої проводився у капсули типу Епіндорфа, що заморожувалася та зберігалася при температурі $-20^{\circ} \mathrm{C}$. Дослідження проводилося на базі Науково-дослідного інституту експерементальної та клінічної медицини Національного медичного університету імені О.О. Богомольця.

Цільове значення Нb визначалося на рівні 110-120 г/л, анемію діагностували за рівня $\mathrm{Hb}<$ 110 г/л [16]. Оптимальним вважали значення феритину на рівні 200-500 мкг/л, насичення трансферину залізом сироватки (\%TSAT) 30-40\%. Рівень C - реактивного білку вважався нормальним при його значенні < 5 мг/л. Лікування анемії здійснювали згідно уніфікованого клінічного протоколу вторинної та третинної медичної допомоги: «Лікування пацієнтів з хронічною хворобою нирок 5 стадії з анемією», затвердженого наказом МОЗ України № 89 від 11.02.2016 року $[3,17]$.

Розподіл хворих на НЗТ за віком проводився згідно з класифікацією Американської асоціації геронтологів. Серед пацієнтів переважали пацієнти середнього та похилого віку, що представлено на рис.1. 


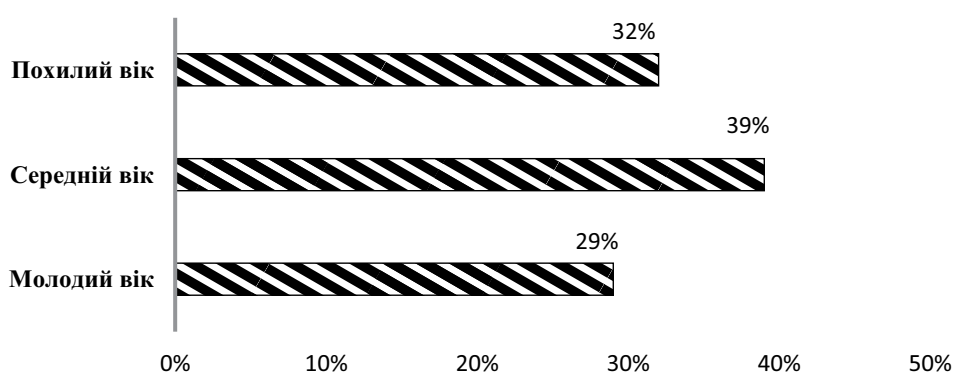

Серед етіологічних чинників, що призвели до розвитку XXН у хворих на ГД превалювали гломерулонефрит та гіпертензивна нефропатія, що представлено на рис. 2.

Рис. 3.1.2. Розподіл хворих на ХХН 5 Д стадії за віком

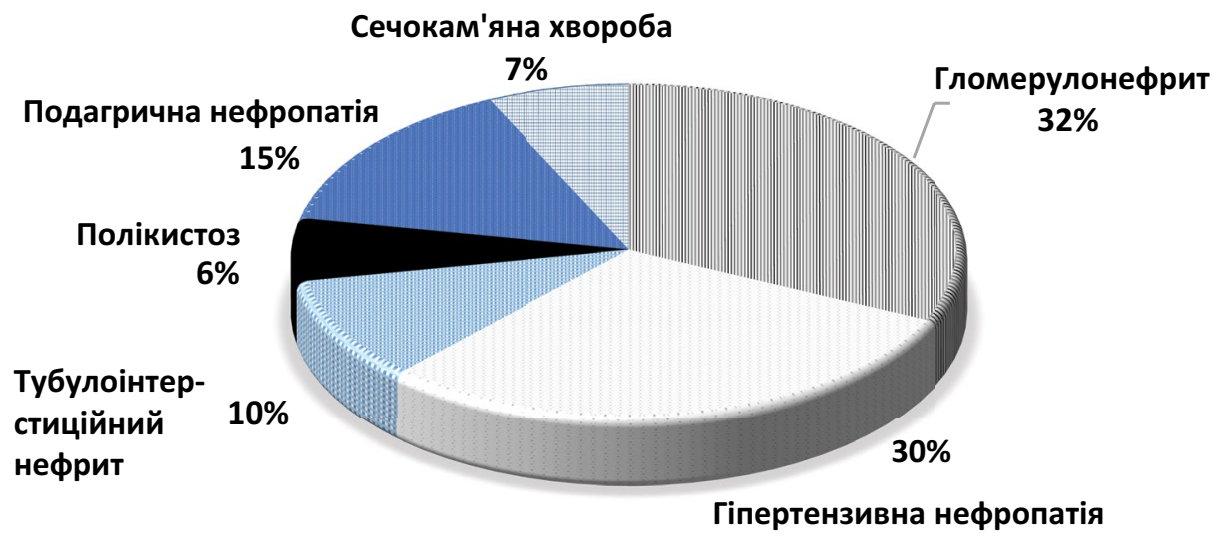

Рис. 2. Розподіл хворих на ХХН 5 Д стадії за нозологіями

В залежності від функціонування епіфізу всі хворі були розподілені на групу хворих зв збереженою МФЕ (n=20) та групу хворих із порушеною
MФE ( $n=110)$. Клінічна характеристика включених у дослідження хворих на ХХН 5 Д стадії продемонстровані у таблиці 1.

Клініко-демографічна характеристика хворих на ГД

Таблиця 1

\begin{tabular}{|c|c|c|c|}
\hline Показник & $\begin{array}{c}\text { Хворі на XXН V Д стадії, } 3 \\
\text { порушеною МФЕ, n=110 }\end{array}$ & $\begin{array}{c}\text { Хворі на XXН V Д стадії, зі } \\
\text { збереженою МФЕ, n=20 }\end{array}$ & $\mathbf{p}$ \\
\hline Стаж АГ & $14,5[8 ; 17]$ & $10[6 ; 14]$ & 0,04 \\
\hline $\mathrm{IMT}, \mathrm{kT} / \mathrm{M}^{2}$ & $21,43[20,3 ; 22,8]$ & $20[19,84 ; 21,21]$ & 0,01 \\
\hline Об'єм талії, см & $89[80 ; 93]$ & $80[77,5 ; 90]$ & 0,04 \\
\hline «Суха» вага, кг & $66,5[58 ; 75]$ & $57[53,5 ; 68,5]$ & 0,04 \\
\hline Міждіалізна прибавка ваги, кг & $3[2,7 ; 3,2]$ & $3,1[2,85 ; 3,25]$ & 0,19 \\
\hline Офісний середній САТ, мм рт ст & $158[142 ; 162]$ & $134[130 ; 137]$ & $<0,001$ \\
\hline Офісний середній ДАТ, мм рт ст & $90[80 ; 96]$ & $80[70 ; 87]$ & $<0,001$ \\
\hline Сатурація трансферину, \% & $32[22,6 ; 36,3]$ & $32,35[27,94 ; 36,05]$ & 0,9 \\
\hline ЗХ, ммоль/л & $4,4[3,11 ; 5,7]$ & $3,37[2,37 ; 5,26]$ & 0,05 \\
\hline ТГ, ммоль/л & $1,56[1,25 ; 1,78]$ & $1,3[1,2 ; 1,4]$ & 0,05 \\
\hline
\end{tabular}

Скорочення: ІМТ - індекс маси тіла, САТ - систолічний артеріальний тиск, ДАТ - діастолічний артеріальний тиск, ЗХ - загальний холестерин, СРБ - С-реактивний білок.

Для реалізації мети та вирішення поставлених завдань, усі пацієнти на ХХН 5 Д стадії, за 4 тижні до початку дослідження стали отримувати аналогічну уніфіковану терапію для корекції анемії та артеріальної гіпертензії.
Статистичну обробку отриманих результатів проведено за допомогою програми Microsoft Office Excel (2010) та IBM Statistics Spss 22. Неперервні дані представлені медіаною та міжквартильним розмахом (Ме [Q25 - Q75]), категоріальні - вира- 
жені у відсотках (\%). Для порівняння нормально розподілених даних використовували критерій Ст'юдента, за невідповідності закону нормального розподілу застосовували непараметричний (U-критерій) Манна-Уітні. Кореляційний зв'язок визначали за методами Пірсона (r) та Спірмена залежно від розподілу показників [3, 15].

Результати. Під час первинного скринінгу порушення мелатонінутворювальної функції епіфізу (МФЕ) у хворих на XXН V Д стадії виявлено у
84,6 \% пацієнтів. Завдяки даному аналізу проведений подальший розподіл хворих в залежності від функціонування епіфізу на групу хворих з порушеною МФЕ ( $n=110)$ та групу пацієнтів зі збереженою функцією епіфізу $(n=20)$ [15].

За добовим профілем МТ виявлено, що хворі 3 дисфункцією епіфізу порівняно 3 хворими групи зі збереженою МФЕ мають достовірно нижчий рівень МТ у слині, що продемонстровано в таблиці 2.

\section{Циркадні ритми мелатоніну у обстежених групах хворих}

Таблиця 2

\begin{tabular}{|l|c|c|c|c|c|}
\hline \multicolumn{1}{|c|}{ Рівень Мт } & $\begin{array}{c}\text { Референтні } \\
\text { значення }\end{array}$ & $\begin{array}{c}\text { Одиниці } \\
\text { виміру }\end{array}$ & $\begin{array}{c}\text { Хворі на ХХH V Д стадії, зі } \\
\text { збереженою МФЕ, n=20 }\end{array}$ & $\begin{array}{c}\text { Хворі на ХХH V д } \\
\text { стадії, 3 порушеною } \\
\text { МФЕ, n=110 }\end{array}$ & p \\
\hline Денний & $<4,9$ & пг/мл & $3,1[2,6 ; 3,5]$ & $1,8[1,5 ; 2,5]$ & $<0,001$ \\
\hline Нічний & $52,3-149$ & пг/мл & $111,0[97,3 ; 130]$ & $19,5[17,8 ; 29,7]$ & $<0,001$ \\
\hline
\end{tabular}

Первинний аналіз показників анемії та запалення виявив більш глибокі порушення у пацієнтів з порушеною МФЕ. Показник феритину групи хворих $з$ дисфункцією епіфізу на 21,5\% вищий за результат групи зі збереженою МФЕ. Хворі $з$ порушеною МФЕ в порівнянні з хворими зі збереженою МФЕ мали статистично значущо вищі показники СРБ на 69,4\% (p<0,001) та нижчі рівні альбуміну на $6 \%(p=0,01)$, що представлено в таблиці 3.

\section{Порівняльна характеристика запалення хворих групи з дисфункцією епіфізу та пацієнтів зі збереженою МФЕ}

\begin{tabular}{|l|c|c|c|}
\hline \multicolumn{1}{|c|}{ Показник } & $\begin{array}{l}\text { Хворі на ХХH VД стадії зі } \\
\text { збереженою МФЕ, } \mathbf{n = 2 0}\end{array}$ & $\begin{array}{c}\text { Хворі на XXH VД стадії } \mathbf{3} \\
\text { порушеною МФЕ, } \mathbf{n = 1 1 0}\end{array}$ & $\mathbf{p}$ \\
\hline СРБ, мг/Мл & $5,5[4,5 ; 8]$ & $18[12 ; 24]$ & $<0,001$ \\
\hline Феритин, нг/мл & $287,55[192 ; 342,5]$ & $366,5[167 ; 539,2]$ & 0,2 \\
\hline Нb, г/л & $85,5[80,5 ; 94]$ & $85[76 ; 92]$ & 0,2 \\
\hline Альбумін, г/л & $36[35 ; 37]$ & $34[32 ; 37]$ & 0,01 \\
\hline
\end{tabular}

Отримані дані свідчать про наявність взаємозв'язку між МФЕ з рівнем анемії та показниками запалення.

Згідно дизайну дослідження в залежності функціонування епіфізу та схеми лікування сформовано три групи хворих. В основну (I) групу увійшло 70 хворих на XXH V стадії, що лікуються ГД з порушеною МФЕ, котрі до стандартної терапії отримували препарат МТ, що приймався один раз на добу о 21:00 в дозі 3,0 мг.

Групу порівняння Ila $(\mathrm{n}=40)$ склали хворі на XXH V стадії з порушеною МФЕ, котрі отримували стандартну терапію. В групу порівняння IIб (n=20) увійшли хворі на XXH V стадії зі збереженою МФЕ на стандартній терапії.

Аналіз отриманих результатів на фоні проведеного 8-тижневого лікування демонструє зменшення проявів анемії у всіх обстежених групах хворих на XXН VД стадії, проте більшою мірою ці покращення спостерігалися в основній групі хворих, що до стандартного лікування додатково отримували препарат МТ.

Так, рівень Нb в основній групі підвищився на $14,3 \%(p<0,001)$, в групі порівняння ІІа його рівень зріс на 5,2\% ( $<<0,01)$, в групі порівняння IIб на $8,2 \%(p<0,001)$.

Значення рівнів загального заліза в основній групі хворих зросли на 54,1\% (р<0,001), в групі порівняння IIa на 7 \% ( $<<0,001)$, в групі ІІб на $9,7 \%$ ( $<<0,001)$. Отриманий нами найвищий приріст рівнів заліза в основній групі підтверджує дані про властивості МТ покращувати метаболізм заліза у хворих на ГД.

Рівень трансферину в групі хворих, що додатково до стандартного лікування отримували МТ підвищився на $12 \%$ ( $<<0,001)$, в групі порівняння 
Ila на 7,7\% $(p=0,4)$, в групі порівняння IIб на 8,2\%. Найкращі рівні відсотку насичення трансферину вдалося досягнути в основній групі, де його рівні зросли на 7,8\% $(p=0,12)$, в групі порівняння ІІб - на 2,2\% ( $p=0,3)$, а в групі порівняння Ila з порушеною МФЕ, що отримували тільки стандартне лікування його рівень зменшився на $5 \%(p=0,3)$, що продемонстровано в таблиці 4.

Рівень Нb та показників обміну заліза в обстежуваних групах

Таблиця 4 на тлі проведеного 2-х місячного лікування

\begin{tabular}{|c|c|c|c|c|c|c|}
\hline \multirow{2}{*}{ Показник } & \multicolumn{2}{|c|}{ Основна група, n = 70} & \multicolumn{2}{|c|}{$\begin{array}{l}\text { Група порівняння Ila (3 } \\
\text { порушеною МФЕ), } \mathrm{n}=40\end{array}$} & \multicolumn{2}{|c|}{$\begin{array}{c}\text { Група порівняння ІІб (зі } \\
\text { збереженою МФЕ), n=20 }\end{array}$} \\
\hline & До лікування & $\begin{array}{c}\text { Після } \\
\text { лікування }\end{array}$ & До лікування & $\begin{array}{l}\text { Після } \\
\text { лікування }\end{array}$ & До лікування & $\begin{array}{l}\text { Після } \\
\text { лікування }\end{array}$ \\
\hline Нb, г/л & $\begin{array}{c}84 \\
{[76 ; 92]}\end{array}$ & $\begin{array}{c}96 \\
{[92 ; 103] \text { * }}\end{array}$ & $\begin{array}{c}86,5 \\
{[76 ; 91,5]}\end{array}$ & $\begin{array}{c}91 \\
{[84,5 ; 98] \text { * }}\end{array}$ & $\begin{array}{c}85,5 \\
{[80,5 ; 94]}\end{array}$ & $\begin{array}{c}92,5 \\
{[88,5 ; 97,5] \text { * }}\end{array}$ \\
\hline $\begin{array}{l}\text { Загальне залізо, } \\
\text { мкмоль/л }\end{array}$ & $\begin{array}{c}10,4 \\
{[8,3 ; 12,01]}\end{array}$ & $\begin{array}{c}15,95 \\
{[11,9 ; 19,1] \text { * }}\end{array}$ & $\begin{array}{c}9,81 \\
{[7,5 ; 11,7]}\end{array}$ & $\begin{array}{c}32 \\
{[22,8 ; 36,3]}\end{array}$ & $\begin{array}{c}10,8 \\
{[8,4 ; 12,3]}\end{array}$ & $\begin{array}{c}11,8 \\
{[10,1 ; 12,9] \text { * }}\end{array}$ \\
\hline $\begin{array}{l}\text { Трансферин, } \\
\text { мкмоль/л }\end{array}$ & $\begin{array}{c}2,1 \\
{[1,6 ; 2,3]}\end{array}$ & $\begin{array}{c}2,3 \\
{[2,2 ; 2,6]}\end{array}$ & $\begin{array}{c}1,95 \\
{[1,48 ; 2,5]}\end{array}$ & $\begin{array}{c}2,1 \\
{[1,6 ; 2,5]}\end{array}$ & $\begin{array}{c}2,1 \\
{[1,8 ; 2,3]}\end{array}$ & $\begin{array}{c}2,3 \\
{[2,2 ; 2,6]}\end{array}$ \\
\hline \% TSAT & $\begin{array}{c}29,8 \\
{[22,8 ; 33,8]}\end{array}$ & $\begin{array}{c}32,1 \\
{[27,1 ; 37,5] \text { * }}\end{array}$ & $\begin{array}{c}33,2 \\
{[21,7 ; 37]}\end{array}$ & $\begin{array}{c}31,5 \\
{[22,4 ; 38,3]}\end{array}$ & $\begin{array}{c}32,3 \\
{[27,9 ; 36,1]}\end{array}$ & $\begin{array}{c}33,1 \\
{[27,3 ; 39,5] \text { * }}\end{array}$ \\
\hline
\end{tabular}

Примітка: - статистична значущість різниць у порівнянні з показником до лікування $(p<0,05)$.

При аналізі показників запалення хворих обстежуваних груп на тлі проведеного лікування, звертає на себе увагу достовірне зниження СРБ у хворих основної групи, що до стандартного лікування отримували препарат МТ. Так, рівень СРБ основної групи знизився на $66,7 \%(p<0,001)$, в групі хворих порівняння IIa на 15,8\% (p<0,05), в групі порівняння ІІб на 9,1\% $(p=0,5)$.

Аналіз рівнів феритину демонструє його зниження в основній групі на 31,2\% (p<0,001), в групі порівняння IIa (з порушеною МФЕ, що отримували стандартну терапію) на $14,9 \%(p=0,5)$ та в групі ІІб (зі збереженою МФЕ) на 12,7\% $(p=0,08)$.

При дослідженні в динаміці рівнів альбуміну звертає на себе увагу підвищення його рівнів в основній групі на $11,8 \%(p<0,001)$ та в групі порівняння Ila на 2,9\% (p<0,05), в групі порівняння ІІб його рівні залишилися без змін, що продемонстровано в таблиці 5.

Таблиця 5

\section{Порівняльна характеристика показників запалення в обстежуваних групах на тлі проведеного 2-х місячного лікування}

\begin{tabular}{|c|c|c|c|c|c|c|}
\hline \multirow{2}{*}{ Показник } & \multicolumn{2}{|c|}{ Основна група, n = 70} & \multicolumn{2}{|c|}{$\begin{array}{l}\text { Група порівняння Ila (3 } \\
\text { порушеною МФЕ), n=40 }\end{array}$} & \multicolumn{2}{|c|}{$\begin{array}{c}\text { Група порівняння ІІб (зі } \\
\text { збереженою МФЕ), n=20 }\end{array}$} \\
\hline & До лікування & $\begin{array}{l}\text { Після } \\
\text { лікування }\end{array}$ & До лікування & $\begin{array}{l}\text { Після } \\
\text { лікування }\end{array}$ & До лікування & $\begin{array}{l}\text { Після } \\
\text { лікування }\end{array}$ \\
\hline $\begin{array}{l}\text { СРБ, } \\
\text { мг/мл }\end{array}$ & $\begin{array}{c}18 \\
{[10 ; 23]}\end{array}$ & $\begin{array}{c}6 \\
{[3 ; 9] \text { * }}\end{array}$ & $\begin{array}{c}19 \\
{[15 ; 25]}\end{array}$ & $\begin{array}{c}16 \\
{[10 ; 22] \text { * }}\end{array}$ & $\begin{array}{c}5,5 \\
{[4,5 ; 8]}\end{array}$ & $\begin{array}{c}6 \\
{[4 ; 7]}\end{array}$ \\
\hline $\begin{array}{l}\text { Феритин, } \\
\text { мкг/л }\end{array}$ & $\begin{array}{c}388,9 \\
{[306,8 ; 556]}\end{array}$ & $\begin{array}{c}267,5 \\
{[245 ; 298,2] \text { * }}\end{array}$ & $\begin{array}{c}399,1 \\
{[193,5 ; 570,7]}\end{array}$ & $\begin{array}{c}339,5 \\
{[180,7 ; 553,3]}\end{array}$ & $\begin{array}{c}287,6 \\
{[192 ; 342,5]}\end{array}$ & $\begin{array}{c}251 \\
{[211,6 ; 313,6]}\end{array}$ \\
\hline $\begin{array}{l}\text { Альбумін, } \\
\text { г/л }\end{array}$ & $\begin{array}{c}34 \\
{[32 ; 37]}\end{array}$ & $\begin{array}{c}38 \\
{[36 ; 41] \text { * }}\end{array}$ & $\begin{array}{c}35 \\
{[31,5 ; 37]}\end{array}$ & $\begin{array}{c}36 \\
{[35 ; 37,5] \text { * }}\end{array}$ & $\begin{array}{c}36 \\
{[35 ; 37]}\end{array}$ & $\begin{array}{c}36 \\
{[36 ; 37]}\end{array}$ \\
\hline
\end{tabular}

Примітка: - статистична значущість різниць у порівнянні з показником до лікування (р<0,05). 
Висновки. Результати проведеного дослідження демонструють зменшення проявів анемії та системного запалення у хворих на XXH V стадії, що лікуються ГД, шляхом нормалізації рівнів $\mathrm{Hb}$, показників обміну заліза, СРБ, феритину та альбуміну на тлі додаткового призначення препарату МТ до стандартного лікування хворих на ГД. Отримані результати підтвер-

\section{ЛITEPATУРA}

1. Besarab A. Optimization of epoetin therapy with intravenous iron therapy in hemodialysis patients. J. Am. Soc. Nephrol. 2000. № 11, P. 530-538

2. Zaritsky J. et al. Hepcidin - a potential novel biomarker for iron status in chronic kidney disease. Clin. J. Am. Soc. Nephrol. 2009. №4, P. 1051-1056.

3. Кондратюк В.Є., Петрова А.С., Карпенко О.В. Клінічна оцінка порушень мелатонінутворювальної функції епіфізу та анемії у хворих на хронічну хворобу нирок 5 стадії, що лікуються гемодіалізом. Нирки. 2020. 9(1): 20-28.

4. Kolesnyk MO, hol. redaktor. Natsionalnyi reiestr khvorykh na khronichnu khvorobu nyrok ta patsiientiv z hostrym poshkodzhenniam nyrok: 2017 rik / uklad. NI Kozliuk, SS Nikolaienko, OO Razvazhaieva; Derzhavna ustanova «Instytut nefrolohii NAMN Ukrainy». Kyiv, 2018.183 s. [In Ukrainian].

5. Pisoni R.L. Anemia management and outcomes from 12 countries in the Dialysis Outcomes and Practice Patterns Study (DOPPS). Am J Kidney Dis. 2004. № 44, P. 94-111.

6. U.S. Renal Data System, USRDS 2013 Annual Data Report: Atlas of Chronic Kidney Disease and EndStage Renal Disease in the United States, National Institutes of Health, National Institute of Diabetes and Digestive and Kidney Diseases, Bethesda, MD, 2013.

7. A. L. M. de Francisco et all. Francisco Inflammation and its impact on anaemia in chronic kidney disease: from haemoglobin variability to hyporesponsiveness. Nephrology Dialysis Transplantation. 2009. 2(1): 18-26.

8. Cobo G, Lindholm B, Stenvinkel P. Chronic inflammation in end-stage renal disease and dialysis. Nephrol Dial Transplant. 2018. 33 (suppl_3)

9. Ito $S$, Higuchi $Y$, Yagi $Y$, Nishijima F, Yamato $H$, et al. (2013) Reduction of indoxyl sulfate by AST-120 attenuates monocyte inflammation джують дані інших експериментальних досліджень в яких продемонстровано антиоксидантні, протизапальні та імунологічні властивості МТ. Широкий спектр функцій МТ дозволяє рекомендувати його додаткове призначення до комплексного лікування хворим на XXН 5 стадії, що лікуються методом гемодіалізу.

related to chronic kidney disease. J Leukoc Biol 93: 837-845.

10. Nowak KL, Chonchol M. Does inflammation affect outcomes in dialysis patients. Semin Dial. 2018. 31(4):388-397. doi:10.1111/sdi.12686

11. Panichi V. Chronic Inflammation and Mortality in dialysis: Effect of Different Renal Replacement Therapies. Results from the RISCAVID Study. Nephrol Dial Transplant. 2008. 23(7): 23372343.

12. Ronco C (ed): Expanded Hemodialysis Innovative Clinical Approach in Dialysis. Contrib Nephrol. Basel, Karger, 2017. 191: 3243. doi: 10.1159/000479254

13. Wang CP, Lu LF, Yu TH, Hung WC, Chiu CA, et al. (2013) Associations among chronic kidney disease, high total p-cresylsulfate and major adverse cardiac events. J Nephrol 26: 111-118.

14. Labonia W., Rubio D., Arias C. Melatonin corrects reticuloendothelial blockade and iron status in haemodialysed patients. Article in Nephrology. 2005. 10(6).

15. Kondratiuk V.E., Petrova A. S., Karpenko O.V. Kharakterystyka melatoninutvoriuvalnoi funktsii epifiza u patsiientiv z khronichnoiu khvoroboiu nyrok $u$ terminalnii stadii.. Klinichna endokrynolohiia ta endokrynna khirurhiia 4 (68) 2019, 94-102

16. ESRD patients in 2013 «A Global Perspective» [Електронний ресурс]. - Режим доступу: http: //www.usrds.org/2013/pdf/v2_ch1_13.pdf.

17. Likuvannia khvorykh na $\mathrm{z}$ khronichnu khvorobu nyrok V HD stadii. Adaptovana klinichna nastanova, zasnovana na dokazakh ta unifikovani klinichni protokoly. - K.: «Polihraf plius», 2016. - 228 s. [In Ukrainian].

18. Петрова А.С. Ефективність мелатоніну в складі комплексної терапії хворих на хронічну хворобу нирок $V$ стадії: дис. доктора філософії 3 галузі знань 22 «Охорона здоров'я».: ДФ 26.003.019 /Анна Сергіївна Петрова; НМУ імені О.О. Богомольця - Київ, 2020. 


\section{PEЗЮME \\ ВЛИЯНИЕ МЕЛАТОНИНА В СОСТАВЕ КОМПЛЕКСНОГО ЛЕЧЕНИЯ НА КЛИНИКО- ЛАБОРАТОРНЫЕ ПОКАЗАТЕЛИ АНЕМИИ И АКТИВНОСТЬ СИСТЕМНОГО ВОСПАЛЕНИЯ У БОЛЬНЫХ С ХРОНИЧЕСКОЙ БОЛЕЗНЮ ПОЧЕК V Д СТАДИИ, НАХОДЯЩИХСЯ НА ЛЕЧЕНИИ ГЕМОДИАЛИЗОМ}

Петрова А.С., Кондратюк В.Е., Карпенко Е.В.

Национальный медицинский университет имени А.А. Богомольца Киев, Украина

Введение. Развитие и прогрессирование хронической болезни почек (ХБП) ассоциируется с неблагоприятными изменениями во всех областях жизни пациентов на гемодиализе (ГД). Несмотря на значительный прогресс в современной медицине, поиск повышения эффективности лечения анемии и системного хронического воспаления у больных с ГД является актуальной задачей сегодняшнего дня.

Цель. Проанализировать эффективность препарата мелатонина у больных ХБП V стадии, лечимых гемодиализом для коррекции анемии и уменьшения проявлений воспаления путем добавления его к стандартному лечению.

Материалы и методы. Обследовано 130 пациентов (50\% женщины) с ХБП 5 стадии, находящихся на лечении методом гемодиализа. Согласно с дизайном исследования в зависимости от функционирования эпифиза и схемы лечения сформированы три группы больных. В основную (I) группу вошли 70 больных с ХБП V стадии, которые лечатся ГД с нарушенной МФЭ, которые до стандартной терапии получали препарат МТ. Группу сравнения IIa $(\mathrm{n}=40)$ составили больные ХБП V стадии с нарушенной МФЭ, получавшие стандартную терапию. В группу сравнения IIб $(\mathrm{n}=20)$ вошли больные ХБП V стадии с сохраненной МФЭ на стандартной терапии.

Результаты и их обсуждение. Добавление мелатонина к комплексной терапии у больных на ГД демонстрирует уменьшение проявлений анемии (повышение уровня $\mathrm{Hb}$ на 14,3\%, p<0,001), улучшение показателей обмена железа (повышение уровня трансферрина на $12 \%, p<0,001)$, белкового обмена (повышение уровня альбумина на $11,8 \%, \mathrm{p}<0,001)$ и системного воспаления (снижение уровня СРБ в 3 раза, $p<0,001$ ), что свидетельствует о противовоспалительных свойствах МТ и его способности улучшать метаболизм железа и белка, устраняя их дефицит.

Выводы. Результаты проведенного исследования демонстрируют уменьшение проявлений анемии и системного воспаления у больных ХБП V стадии, которые лечатся ГД, путем нормализации уровней $\mathrm{Hb}$, показатели обмена железа, СРБ, ферритина и альбумина на фоне дополнительного назначения препарата МТ для стандартного лечения больных ГД. Полученные результаты подтверждают данные других экспериментальных исследований, где продемонстрированы антиоксидантные, противовоспалительные и иммунологические свойства МТ. Широкий спектр функций МТ позволяет рекомендовать его дополнительное назначение к комплексному лечению больным ХБП V стадии, которые лечатся методом гемодиализа.

Ключевые слова: Хроническая болезнь почек, гемодиализ, эпифиз, мелатонин, мелатонинуобразующая функция эпифиза, анемия, гемоглобин, воспаление, ферритин, С-реактивный белок, альбумин.

\section{SUMMARY}

\section{THE INFLUENCE OF MELATONIN IN THE COMPLEX TREATMENT ON CLINICAL AND LABORATORY PARAMETERS ACTIVITY ANEMIA AND SYSTEMIC INFLAMMATION IN PATIENTS WITH CHRONIC KIDNEY DISEASE V D STAGE, WHO ARE TREATED WITH HEMODIALYSIS}

Petrova A.S., Kondratyuk V.E., Karpenko E.V.

Bogomolets National Medical University Kyiv, Ukraine

Introduction. The development and progression of chronic kidney disease (CKD) are associated with adverse changes in all areas of the life of patients on hemodialysis (HD). Despite significant advances in modern medicine, the search for improved treatment of anemia and systemic chronic inflammation in patients with HD is an urgent task today.

Goal. To analyze the effectiveness of the drug melatonin in patients with CKD stage $V$ treated with hemodialysis to correct anemia and reduce inflammation, by adding it to standard treatment.

Materials and methods. 130 patients $(50 \%$ of women) with stage 5 CKD undergoing hemodialysis were examined. According to the study design, depending on the functioning of the pineal gland and the treatment regimen, three groups of patients were formed. The main (I) group included 70 patients with CKD stage $V$ treated with HD with impaired MFE, who received the drug MT before standard therapy. The comparison group Ila $(n=40)$ consisted of patients with CKD stage $\mathrm{V}$ with impaired MFE, who received standard therapy. The comparison group Illb $(n=20)$ included patients with CKD stage $V$ with preserved MFE on standard therapy. All patients underwent clinical and laboratory studies at the start of treatment and after 8 weeks of treatment, which included general clinical and biochemical blood tests, and mandatory determination of melatonin concentration in saliva.

Results and discussion. The addition of melatonin to complex therapy in patients with HD shows a decrease in the manifestations of anemia (increased $\mathrm{Hb}$ by $14.3 \%$, $\mathrm{p}<0.001$ ), improved iron metabolism (increased transferrin by $12 \%, p<0.001$ ), protein metabolism (increased albumin by $11.8 \%, p<0.001$ ) and systemic inflammation (decrease in CRP levels by 3 times, $p<0.001$ ), which indicates the anti-inflammatory properties of MT and its ability to improve iron and protein metabolism, eliminating their deficiency.

Conclusions. The results of the study show a reduction in anemia and systemic inflammation in patients with Stage V Chronic Kidney Disease treated with HD by normalizing $\mathrm{Hb}$ levels, iron metabolism, CRP, ferritin 
and albumin with additional administration of MT to standard treatment of patients with HD. The obtained results confirm the data of other experimental studies, which demonstrated the antioxidant, anti-inflammatory and immunological properties of MT. A wide range of MT functions allows to recommend its additional appointment to the complex treatment of patients with Stage V Chronic Kidney Disease treated by hemodialysis.

Keywords: chronic kidney disease, hemodialysis, pineal gland, melatonin, melatonin-forming function of the pineal gland, anemia, hemoglobin, inflammation, ferritin, C-reactive protein, albumin.

\section{АВТОРСЬКА ДОВІДКА}

\section{Петрова Анна Сергіївна}

Національний медичний університет імені О.О. Богомольця,

К.м.Н., асистент

Адреса: вулиця Петра Запорожця, 26,

Київ, 02125

моб.: +380931971748

E-mail: anna2311doc@ukr.net ORCID: https://orcid.org/0000-00021648-1481.

\section{Кондратюк Віталій Євгенович}

Національний медичний університет імені О.О. Богомольця,

завідувач кафедри, д.м.н., професор

Адреса: вулиця Петра Запорожця, 26,

Київ, 02125

моб.: +380503872902

E-mail: kondratiuk_v@ukr.net

ORCID: https://orcid.org/0000-0002-

4891-2338

\section{Карпенко Олена \\ В'ячеславівна}

Національний медичний університет імені О.О. Богомольця,

к.м.н., доцент

Адреса: вулиця Петра Запорожця, 26, Київ, 02125

моб.: +380957199007

E-mail: karpenko05.12@ukr.net

ORCID: https://orcid.org/0000-0003-

1763-0618

\section{Петрова Анна Сергеевна}

Национальный медицинский университет имени А.А. Богомольца, к.м.Н., ассистент

Адрес: улица Петра Запорожца, 26, Киев, 02125

моб.: +380931971748

E-mail: anna2311doc@ukr.net ORCID: https://orcid.org/0000-00021648-1481.

\section{Кондратюк Виталий \\ Евгеньевич}

Национальный медицинский университет имени А.А. Богомольца, заведующий кафедрой, д.м.н., профессор

Адрес: улица Петра Запорожца, 26, Киев, 02125

моб.: +380503872902

E-mail: kondratiuk_v@ukr.net ORCID: https://orcid.org/0000-00024891-2338

\section{Карпенко Елена Вячеславовна}

Национальный медицинский университет имени А.А. Богомольца, к.м.н., доцент

Адрес: улица Петра Запорожца, 26, Киев, 02125

моб.: +380957199007

E-mail: karpenko05.12@ukr.net ORCID: https://orcid.org/0000-00031763-0618

\section{Petrova Anna}

Bogomolets National Medical

University,

$\mathrm{PhD}$, assistant

Address: 26 Petro Zaporozhets Street, Kyiv, 02125

mob.: +380931971748

E-mail: anna2311doc@ukr.net ORCID: https://orcid.org/0000-00021648-1481.

\section{Kondratyuk Vitalii}

Bogomolets National Medical

University,

head of Department, MD, Professor

Address: 26 Petro Zaporozhets Street, Kyiv, 02125

mob.: +380503872902

E-mail: kondratiuk_v@ukr.net

ORCID: https://orcid.org/0000-00024891-2338

\section{Karpenko Olena}

Bogomolets National Medical

University,

$\mathrm{PhD}$, docent

Address: 26 Petro Zaporozhets Street, Kyiv, 02125

mob.: +380957199007

E-mail: karpenko05.12@ukr.net

ORCID: https://orcid.org/0000-0003-

1763-0618 